\title{
Epigenetic Targets in the Treatment of cancer
}

\author{
Giovanni Codacci-Pisanelli* \\ Department of Medical and Surgical Sciences and Biotechnology, Sapienza University of Rome, Italy
}

Submission: April 18, 2017; Published: June 13, 2017

*Corresponding author: Giovanni Codacci-Pisanelli*, Department of Medical and Surgical Sciences and Biotechnology, Sapienza University of Rome, Italy, Tel: 3314881377; Fax: 0623317568; Email: Giovanni.Codacci-Pisanelli@uniroma1.it

\section{Introduction}

After the identification of genetic elements in DNA it became apparent that specific cell functions required sophisticated mechanism to regulate gene expression [1]. This is obtained by modifications of DNA and of histones: methyl residues can be inserted on DNA (cytidine) or on histones (lysine or arginine), while acetyl groups on histones are added or removed to turn genes on or off. The epigenetic machinery is very complex consisting of different protein complexes responsible for the different steps required: by applying a simplification that is certainly inaccurate but useful in practical terms, proteins involved in epigenetic regulation can be divided into writers, erasers and readers. When it was found that these mechanisms may also be responsible for the malignant behaviour of transformed cells [2,3] researchers started to look for specific inhibitors that could be used in the "epigenetic treatment" of patients [4].

Some drugs have long been in clinical use under a different label: this applies to Valproic acid and to anti metabolites such as Cytrarabine (Cytosine arabinoside), 5-aza-cytidine, and Decitabine. Cytarabine was used according to different protocols: when given in low, repeated doses it did not result in relevant anti proliferative effect and it was able to induce sporadic but consistent cases of differentiation of leukemic cells [5]. One of the advantages of these regimens was their very limited toxic side effects which allowed prolonged and well tolerated treatment even in elderly patients [6]. By today standards these should be considered in every respect "epigenetic" treatments. On the other hand the term "epigenetic treatment" could be used for any therapy that leads to reprogramming of gene expression. All-trans retinoic acid is an exceptional example of how malignant cells can be redirected toward physiological development through pharmacological manipulation of gene expression [7]. In a similar way estrogens and anti-estrogens regulate gene expression through epigenetic control $[8,9]$ and should therefore be included in this definition.

Concerning histone acetylation-deacetylation several molecules acting on these mechanisms are now in clinical use: the first was Valproic acid, while Belinostat, Panobinostat and
Vorinostat (SAHA) were later added to this list. Today a number of molecules acting on similar or on different targets have been registered for clinical use, especially in haematological malignancies $[10,11]$, or are in different phases of clinical evaluation [12]. With reference to solid tumours we recently reviewed studies reporting on their epigenetic treatment [13].

Traditionally the biological characterization of malignant cells is more accurate in haematology and this may at least in part explain why epigenetic treatment is in a more advanced phase for haematological malignancies [14]. Progress however is also being made in solid tumours: several histological types have been carefully analysed and today a sort of "epigenetic signature" can even be used to identify carcinomas of unknown origin [15]. Brain tumours are among the histological types that have been studied in detail [16] and several potential epigenetic targets have been identified $[17,18]$. The identification of isocitrate dehydrogenase (IDH) mutations as a prognostic element [19-21] is of particular interest. Mutated IDH can produce $\mathrm{R}(-)$-2-hydroxyglutarate which is under many aspects an "on co metabolite" [22]. IDH role and the relevance of its mutations have been well described [23] and since this enzyme and its products play a role in the regulation of cell metabolism it appears that epigenetic control and energetic metabolism are strictly related [24-28].

\section{Conclusion}

The use of molecules that interfere with the epigenetic regulation of gene expression is a promising strategy especially in tumour types that do not respond to traditional anticancer agents. In order to accelerate drug development we need to identify those tumours that have a better probability of responding. The crossroad between epigenetics and cellular energetic metabolism is a particularly stimulating field of research that may bring excellent results in the future if adequately exploited.

\section{References}

1. Waddington C (2012) The epigenotype 1942. Int J Epidemiol 41(1): 10-13. 
2. Feinberg A, Tycko B (2004) The history of cancer epigenetics. Nat Rev Cancer 4(2): 143-153.

3. Koschmann C, Nunez FJ, Mendez F, Brosnan-Cashman J, Meeker AK, et al. (2017) Mutated chromatin regulatory factors as tumor drivers in cancer. Cancer Res 77(2): 227-233.

4. Dawson MA, Kouzarides T (2012) Cancer epigenetics: from mechanism to therapy. Cell 150(1): 12-27.

5. Franchi F, Seminara P, Codacci-Pisanelli G (1986) Cytosine arabinosideinduced differentiation and killing: unresolved questions. Folia Haematol Int Mag Klin Morphol Blutforsch 113(3): 358-364.

6. Petti MC, Mandelli F, Zagonel V, De Gregoris C, Merola MC, et al. (1993) Pilot study of 5-aza-2'-deoxycytidine (Decitabine) in the treatment of poor prognosis acute myelogenous leukemia patients: preliminary results. Leukemia 1: 36-41.

7. de Thé H, Chen Z (2010) Acute promyelocytic leukaemia: novel insights into the mechanisms of cure. Nat Rev Cancer 10(11): 775-783.

8. Badia E, Duchesne MJ, Semlali A, Fuentes M, Giamarchi C, et al. (2000) Long-term hydroxytamoxifen treatment of an MCF-7-derived breast cancer cell line irreversibly inhibits the expression of estrogenic genes through chromatin remodeling. Cancer Res 60(15): 4130-4138.

9. Stone A, Valdés-Mora F, Gee JM, Farrow L, McClelland RA, et al. (2012) Tamoxifen-induced epigenetic silencing of oestrogen-regulated genes in anti-hormone resistant breast cancer. PloS one 7(7): e40466.

10. Wouters B, Delwel R (2016) Epigenetics and approaches to targeted epigenetic therapy in acute myeloid leukemia. Blood 127(1): 42-52.

11. Kadia T, Ravandi F, Cortes J, Kantarjian H (2015) Toward individualized therapy in acute myeloid leukemia: a contemporary review. JAMA oncology 1(6): 820-828.

12. Shortt J, Ott CJ, Johnstone RW, Bradner JE (2017) A chemical probe toolbox for dissecting the cancer epigenome. Nat Rev Cancer 17(3): 160-183.

13. Nervi C, De Marinis E, Codacci PG (2015) Epigenetic treatment of solid tumours: a review of clinical trials. Clin Epigenetics 7: 127.

14. Kon Kim T, Gore SD, Zeidan AM (2015) Epigenetic therapy in acute myeloid leukemia: current and future directions. Semin Hematol 52(3): 172-183

15. Moran S, Martínez-Cardús A, Sayols S, Musulén E, Balañá C, et al. (2016) Epigenetic profiling to classify cancer of unknown primary: a multicentre, retrospective analysis. Lancet Oncol 17(10): 1386-1395.

This work is licensed under Creative

Commons Attribution 4.0 License

DOI: 10.19080/NAPDD.2017.01.555567
16. Bai H, Harmancı AS, Erson-Omay EZ, Li J, Coşkun S, et al. (2016) Integrated genomic characterization of IDH1-mutant glioma malignant progression. Nat Genet 48(1): 59-66.

17. Mohammad F, Weissmann S, Leblanc B, Pandey DP, Højfeldt JW, et al. (2017) EZH2 is a potential therapeutic target for H3K27M-mutant pediatric gliomas. Nat Med 23(4): 483-494.

18. Piunti A, Hashizume R, Morgan MA, Bartom ET, Horbinski CM, et al. (2017) Therapeutic targeting of polycomb and BET bromodomain proteins in diffuse intrinsic pontine gliomas. Nat Med 23(4): 493-500.

19. Jeanette E EP, Daniel HL, Annette MM, Kyle MW, Paul AD, et al. (2015) Glioma groups based on $1 \mathrm{p} / 19 \mathrm{q}$, IDH, and TERT promoter mutations in tumors. N Engl J Med 372(26): 2499-2508.

20. Cancer G, Brat DJ, Verhaak RG, Aldape KD, Yung WK, et al. (2015) Comprehensive, integrative genomic analysis of diffuse lower-grade gliomas. N Engl J Med 372(26): 2481-2498.

21. Xia L, Wu B, Fu Z, Feng F, Qiao E, et al. (2015) Prognostic role of IDH mutations in gliomas: a meta-analysis of 55 observational studies. Oncotarget 6(19): 17354-17365.

22. Dang L, White DW, Gross S, Bennett BD, Bittinger MA, et al. (2009) Cancer-associated IDH1 mutations produce 2-hydroxyglutarate. Nature 462(7274): 739-744.

23. Cairns RA, Mak TW (2013) Oncogenic isocitrate dehydrogenase mutations: mechanisms, models, and clinical opportunities. Cancer Discov 3(7): 730-741.

24. Carrer A, Wellen KE (2015) Metabolism and epigenetics: a link cancer cells exploit. Curr Opin Biotechnol 34: 23-29.

25. Hirschey MD, DeBerardinis RJ, Diehl AM, Drew JE, Frezza C, et al. (2015) Dysregulated metabolism contributes to oncogenesis. Semin Cancer Biol 35: S129-S150.

26. Gaude E, Frezza C (2016) Tissue-specific and convergent metabolic transformation of cancer correlates with metastatic potential and patient survival. Nat Commun 7: 13041.

27. Kaelin W, McKnight S (2013) Influence of metabolism on epigenetics and disease. Cell 153(1): 56-69.

28. Kinnaird A, Zhao S, Wellen KE, Michelakis ED (2016) Metabolic control of epigenetics in cancer. Nat Rev Cancer 16(11): 694-707.

\section{Your next submission with Juniper Publishers will reach you the below assets}

- Quality Editorial service

- Swift Peer Review

- Reprints availability

- E-prints Service

- Manuscript Podcast for convenient understanding

- Global attainment for your research

- Manuscript accessibility in different formats

( Pdf, E-pub, Full Text, Audio)

- Unceasing customer service

Track the below URL for one-step submission https://juniperpublishers.com/online-submission.php 